\title{
Penerapan Media CLIS (Children Learning In Science) untuk Meningkatkan Hasil Belajar Matematika Materi Bangun Ruang
}

\author{
Sri Wahyuni*
}

SDN Candiwatu

\section{A R T I C L E I N F O}

Article history:

Received 12 December 2019

Received in revised form 01 January 2020

Accepted 30 January 2020

Available online 27

February 2020

Kata Kunci:

Hasil Belajar, Matematika, Media CLIS.

Keywords:

Learning Outcomes, Mathematics, CLIS Media.

A B S T R A K

Tujuan penelitian ini adalah untuk meningkatkan hasil belajar siswa dalam pembelajaran matematika Bangun Ruang menggunakan media CLIS pada siswa kelas 1 SD N Candiwatu Pacet.. Hipotesis tindakan dalam penelitian ini adalah menggunakan media CLIS dapat meningkatkan hasil belajar siswa pada pembelajaran matematika kelas 1 SD N Candiwatu Pacet tahun pelajaran 2017/2018.Jenis penelitian yang digunakan adalah Penelitian Tindakan Kelas (PTK).Proses Penelitian yang digunakan adalah penelitian yang dikemukakan oleh Kemmis dan Taggart yang menggunakan siklus sistem spiral yang maing-masing siklus terdiri dari rencana, tindakan, observasi, dan refleksi. Subjek dalam penelitian ini adalah siswa kelas 1 SD $\mathrm{N}$ Candiwatu Pacet yangberjumlah 20 orang. Sedangkan obyek penelitian adalah keseluruhan proses pada penerapan media CLIS di SD N Candiwatu Pacet. Data hasil penelitian diperoleh dari hasil observasi, tes akhir siklus dan dokumentasi. Untuk analisis data kuantitatif diolah dengan rumusrumus statistik, sedangkan analisis data kualitatif dilakukan dengan mendeskripsikan seluruh data yang tersedia dari lembar observasi dan dokumentasi.Hasil penelitian menunjukkan bahwa hasil belajar matematika siswa dengan menggunakan media CLIS mengalami peningkatan. Hal ini ditunjukkan dengan adanya peningkatan rata-rata hasil belajar Matematika siswa kelas 1 sebesar 49,01\%. Selain itu dari hasil analisis data observasi mengalami peningkatan yaitu dari $46,7 \%$ aspek terpenuhi menjadi $96,7 \%$ aspek. Karena pembelajaran dengan menggunakan media CLIS dapat meningkatkan hasil belajar matematik

\section{A B S T R A C T}

The purpose of this study was to improve student learning outcomes in learning mathematics using CLIS media in grade 1 students at SD N Candiwatu Pacet. The action hypothesis in this study was to use CLIS media to improve student learning outcomes in mathematics learning at grade $1 S D$ N Candiwatu Pacet 2017 / 2018 academic year. This research was Classroom Action Research (CAR). The research process proposed by Kemmis and Taggart that uses a spiral system cycle, each cycle consisting of plans, actions, observations, and reflections. The subjects in this study were grade 1 students at SD N Candiwatu Pacet with20 students. While the object of research is the whole process in the application of CLIS media in SD N Candiwatu Pacet. The research data were obtained from observations, end of cycle tests and documentation. For quantitative data analysis, it processed with statistical formulas, while qualitative data analysis is done by describing all available data from observation and documentation sheets. The results of the study show that students' mathematics learning outcomes using CLIS media have increased. It indicated by an increase in the average learning outcomes of students in grade 1 by $49.01 \%$. In addition, observational data analysis results have increased, from $46.7 \%$ of aspects fulfilled to $96.7 \%$ of aspects. Because learning by using CLIS media can improve mathematical learning outcomes 


\section{Pendahuluan}

Perkembangan pada era globalisasi sekarang ini menuntut adanya sumber daya manusia yang berkualitas tinggi dimana hal ini merupakan kunci untuk mencapai tujuan pembangunan. Salah satu wadah untuk mengusahakan peningkatan kualitas sumber daya manusia tersebut adalah dengan pendidikan. Sumitro, Et.al (2006:17-19) menyatakan pendidikan merupakan proses pengembangan dan perilaku manusia secara keseluruhan. Selanjutnya pendidikan berguna untuk mengembangkan nilai-nilai baru dalam menghadapi tantangan ilmu, teknologi dan dunia modern. Pembelajaran merupakan suatu kombinasi yang tersusun meliputi unsurunsur manusiawi, material, fasilitas, perlengkapan dan prosedur dan yang saling mempengaruhi tujuan pembelajaran (Oemar Hamalik, 2005:57). Selanjutnya Ety Syarifah (2009:6-8) memaparkan Pembelajaran memiliki tiga komponen yang saling berkaitan. Ketiga komponen tersebut adalah tujuan pembelajaran, proses pembelajaran dan penilaian pembelajaran.

Keberhasilan pendidikan tidak lepas dari proses belajar mengajar,yang di dalamnya meliputi beberapa komponen yang saling terkait antara lain guru (pendidik), siswa ( peserta didik),materi (bahan),media ( alat/ sarana) dan metode pembelajaran atau pola penyampaian bahan ajar. Dalam proses belajar mengajar siswa mendapatkan sejumlah pengetahuan,nilai keteladanan yang membentuk sikap serta ketrampilan yang berguna baginya dalam menyikapi berbagai masalah kehidupan.Menurut syaiful Bahri Djamarah (2012:44-45) proses belajar mengajar di persekolahan didasari sebuah teori yang menyatakan bahwa " belajar pada hakekatnya adalah perubahan yang terjadi dalam diri seseorang setelah berakhirnya melakukan aktivitas belajar.Sedangkan mengajar merupakan proses mengatur,mengorganisasi lingkungan yang ada di sekitar anak didik melakukan proses belajar. Selanjutnya,pada tahap berikutnya mengajar adalah proses memberikan bimbingan atau bantuan kepada anak didik dalam melakukan proses belajar (Nana Sudjana dan Syaiful Bahri Djamarah,2012:45). Untuk itu guru dan siswa memiliki peran penting dalam mewujudkan proses belajar mengajar yang kondusif.

Proses belajar mengajar akan terorganisir dengan baik apabila terdapat kesiapan siswa dengan segala potensinya yang meliputi aspek kognitif,afektif,psikmotorik,juga guru yang mampu menciptakan suasana belajar yang mendukung pemberdayaan seluruh potensi yang di miliki siswa. Potensi anak didik perlu ditingkatkan melalui arahan dan bimbingan yang diberikan oleh guru di sekolah. Metode pembelajaran memegang peranan penting dalam rangkaian sistem pembelajaran. Untuk itu diperlukan kecerdasan dan kemahiran guru dalam memilih metode pembelajaran.Agar tujuan belajar baik secara kognitif,afektif maupun psikomotor dapat tercapai,maka metode pembelajaran diarahkan mencapai sasaran tersebut yaitu lebih banyak menekankan pembelajaran proses ( Sumiati dan Asra,2016:91). Metode pembelajaran menekankan pada proses belajar siswa secara aktif dalam upaya memperoleh kemampuan belajar.

Dalam proses pembelajaran,seorang guru berusaha dapat menciptakan dan menggunakan berbagai macam metode,agar pembelajaran tidak membosankan bagi siswa. Guru yang baik,menghargai setiap usaha yang dilakukan oleh siswa dan menghargai hasil kerja siswa,serta memberikan rangsangan atau dorongan kepada siswa supaya mampu berbuat dan berpikir,sambil menghasilkan karya dan pikiran kreatif, Oleh karenanya,seorang guru perlu menggunakan metode dan media pembelajarannyan yang bervariasi,seta menyediakan beragam pengalaman belajar melalui interaksi dengan isi atau materi pembelajaran.

Proses Pembelajaran yang menyenangkan merupakan salah satu faktor yang dapat menunjang keberhasilan suatu pembewlajaran .Ketika pembelajaran ini dilakukan dengan cara menyenangkan,maka materi-materi yang dipelajari akan mudah diterima dan dimengerti dengan baik oleh siswa. Agar dalam pembelajaran Matematika tidak monoton dan lebih bervariasi,maka bisa diterapkan berbagai macam metode atau cara pembelajarannya yang di lakukan oleh guru sekali-sekali perlu di praktekkan. Tujuannya dari penggunaan metode maupun media pembelajaran yang bervarisi tersebut adalah bermanfaat untuk memperjelas penyampaian materi pelajaran dan untuk mengatasi keterbatasan guru dalam mengajar,disamping itu juga dapat diarahkan perhatian siswa agar lebih fokus pada materi pelajaran yang disamapikan.

Berdasarkan uraian diatas dapat disimpulkan bahwa dalam proses belajar mengajar,diharapkan adanya suasana pembelajaran yang dapat mengembangkan kemampuan siswa secara aktif. Namun pada proses pembelajaran berlangsung pada umumnya masih terpusat oleh guru (teacher centered ). Dan bukan pada siswa (students Centered). Kondisi ini di pertegas pendapat yang disampaikan oleh Thomas Armstrong dalam bukunya" Sekolah Para Juara" juga mendiskripsikan model pembelajaran klasik yang antara lain memunculkan asumsi-asumsi : Pertama, para guru cendurung memisahkan atau memberikan identifikasi kepada para muridnya sebagai murid-murid yang pandai di satu sisi, dan murid-murid yang bodoh di sisi lain.Kedua suasana kelas cenderung monoton dan membosankan. Hal ini di karenakan para guru biasanya banyak bertumpu pada satu atau dua jenis kecerdasan dalam mengajar yaitu cerdas 
berbahasa dan cerdas berlogika. Solusi yang dapat ditawarkan untuk permasalahan tersebut adalah penggunaan model pembelajaran yang bisa diterapkan sebagai salah satu inovasi pembelajaran Salah satunya adalah model pembelajaran belajar IPA (Children Learning In Science). Samatowa (2010:74) menyatakan bahwa model pembelajaran Children Learning In Science (CLIS) termasuk dalam model yang menganut pandangan kontruktivisme. Model ini dikembangkan oleh Driver di Inggris tahun 1998. Rangkaian fase pembelajaran pada model CLIS oleh Driver diberi nama general structure of a contructivism teaching sequence. Menurut Suryani (2018) Media merupakan salah satu kelengkanpan yang cukup penting yang diperlukan dalam proses pembelajaran. Penggunaan media pembelajaran yang tepat akan dapat meningkatkan pemahaman siswa dalam proses belajar mengajar. Oleh karena itu, dalam proses belajar mengajar guru berusaha menggunakan media yang tepat agar tujuan-tujuan yang diinginkan dapat tercapai dalam diri siswa. Model pembelajaran adalah suatu rencana atau pola yang dapat digunakan untuk membentuk kurikulum (rencana pembelajaran jangka panjang), merancang bahan-bahan pembelajaran, dan membimbing pembelajaran di kelas atau yang lain. Model pembelajaran dapat dijadikan bahan pilihan, artinya para guru dapat memilih model pembelajaran yang sesuai dan efisien untuk mencapai tujuan pendidikannya (Rusman, 2012:133). Model Pembelajaran CLIS merupakan model pembelajaran yang berusaha mengembangkan ide atau gagasan siswa tentang suatu masalah tertentu dalam pembelajaran serta merekontruksi ide atau gagasan berdasarkan hasil pengamatan dan percobaan (Widiyarti, 2012). Menurut Budiarti (2014) model pembelajaran CLIS ini secara tidak disadari akan membantu siswa untuk mengubah (merekonstruksi) konsepsi awal siswa yang salah menuju konsepsi yang benar dengan melewati pembelajaran yang menarik dan bermakna. Menurut Nurani (2017) model pembelajaran Children Learning In Science mempunyai tujuan agar pembelajaran dapat bertahan lama karena pembelajaran CLIS memuat tahap-tahap kegiatan siswa dalam mem-pelajari konsep yang diajarkan. Menurut Ismail (2015) Model pembelajaran CLIS adalah kerangka berpikir untuk menciptakan lingkungan yang memungkinkan terjadinya kegiatan belajar mengajar yang melibatkan siswa dalam kegiatan pengamatan dan percobaan dengan menggunakan Lembar Kerja Siswa (LKS). Menurut Irawati (2014) Adapun tahap-tahap model pembelajaran CLIS ini yaitu: (1) Orientation (orientasi), (2) Elicitation of ideas (pemunculan gagasan), (3) Restructuring of ideas (penyusunan ulang gagasan), (4) Application of ideas (penerapan gagasan) dan (5) Review change in ideas (mengkaji ulang perubahan gagasan).

Berdasarkan latarbelakang tersebut diatas, maka penulis mengambil judul "Penerapan Model Pembelajaran CLIS untuk meningkatkan hasil belajar Matematika Materi Bangun Ruang Siswa Kelas 1A SD N Candiwatu Pacet.

\section{Metode}

Penletian ini dilaksanakn dengan 3 tahapan yaitu 1) Perencanaan, kegiatan yang dilakukan oleh peneliti pada tahap perencanaan adalah: 1)Peneliti melakukan analisis kurikulum untuk menentukan standar kompetensi dan kompetensi dasar yang disampaikan kepada siswa dengan menggunakan media pembelajaran CLIS, 2) Membuat RPP siklus I dengan model pembelajaran berbased CLIS, 3) Membuat lembar observasi siklus I untuk melihat bagaimana kondisi belajar mengajar dikelas ketika latihan dan kerja kelompok dilaksanakan, 4) Membuat Lembar Kerja Siswa siklus I, 5) Membentuk kelompok yang bersifat heterogen baik dari segi kemampuan akademis, jenis pembelajaran dengan menggunakan mediapembelajaran CLISpada siklus I, dan 6) Menyusun alat evaluasi pembelajaran berdasarkan perkembangan untuk dilaksanakan pada siklus II serta menyiapkan instrumen pendukung pembelajaran lainnya.

Tahap kedua yaitu prosedur pelaksanaan tindakan dan pengamatan, selama pembelajaran langsung dilakukan observsi untuk mengetahui prosedur pelaksanaan pemebelajaran berbasis CLIS dalam meningkatkan hasil belajarpada proses pembelajaran Matematika. Langkah selanjutnya bagi peneliti adalah pelaksanaan. Pada tahap ini perencanaan yang sudah dibuat peneliti akan dilaksanakan dalam kegiatan pembelajaran. Tahap pengamatan atau observasi dilakukan bersamaan dengan pelaksanaan tindakan. Pada tahap ini peneliti di bantu oleh guru atau teman sejawat untuk mencatat semua hal yang diperlukan dalam penelitian berupa pengumpulan data. Ketika dilaksanakan kegiatan pembelajaran kebanyakan siswa yang tidak tahu dan tidak paham, sehingga tidak bisa menjawab pertanyaan yang berkenaan dengan soal-soal yang berhubungan dengan "Bangun Ruang". Karena ketidakpahaman dan ketidakmapuan dalam menjawab soal-soal yang berhubungan dengan "Bangun Ruang", suasana kelas tampak gaduh dan sulit dikendalikan. 
Tahap yang terahir merupakann kegiatan untuk mengemukakan kembali apa yang sudah dilakukan. Istilah refleksi berasal dari kata bahasa Inggris reflection yang diterjemahkan dalam bahasa Indonesia. Pada tahap ini peneliti menyimpulkan data atau hasil yang diperoleh selama proses penelitian itu berlangsung. Selain itu juga dimaksudkan sebagai upaya untuk memahami proses, masalah, persoalan, dan kendala nyata dalam proses tindakan. Dalam hal ini peneliti melakukan penilaian sebagai tugas akhir dari siklus.

Penelitian tindakan kelas ini dilaksanakan secara di SDN Cadiwatu Pacet. Yang dijadikan subjek dalam penelitian tindakan kelas ini adalah siswa kelas1A, dengan jumlah siswa 20 orang yang terdiri dari 9 orang lakii-laki dan 11 orang perempuan. Sebelum penelitian tindakan kelas ini dilakukan, peneliti melakukan persiapan berupa kegiatan-kegiatan sebagai berikut : 1) Studi awal tentang pelaksanaan peningkatan keaktifan siswa dalam pembelajaran Matematika siswa kelas 1A, 2) Mengidentifikasi permasalahan dalam pelaksanaan peningkatan keaktifan siswa dalam pembelajaran Matematikasiswa kelas 1A, 3) Merencanakan rencana penelitian, pada tahap ini peneliti menyusun serangkaian kegiatan secara menyeluruh berupa siklus-siklus tindakan kelas meliputi peningkatan keaktifan siswa dalam pembelajaran Matematika meliputi peningkatan keaktifan siklus I dan II, 4) Menyusun instrumen sebagai pedoman observasi terhadap pelaksanaan keaktifan siswa kelas 1A.mengikuti pembelajaran Matematika dalam penelitian tindakan kelas, 5) Penyusunan indikator keberhasilan model pembelajarandengan menggunakan Mesia CLIS yang berupa keaktifan siswa kelas 1A dalam setiap pembelajaran Matematika

Dalam penelitian ini digunakan satu jenis instrumen penelitian sebagai alat pengumpulan data, yaitu: instrumen tes, yang terdiri atas: (a) Medial Pembelajaran CLIS dan (b) tes hasil belajar siswa.

1. Instrumen model Pembelajaran

Dalam penelitian ini, instrumen digunakan untuk menentukan tipe model pembelajaran yang sesuai dalam proses belajar mengajar. Instrumen berbentuk tes objektif pilihan ganda dengan dua alternatif jawaban sebanyak 10 butir soal.

2. Instrumen Hasil Belajar Siswa

Instrumen tes digunakan untuk mengukur variabel hasil belajar siswa. Instrumen tes ini berbentuk tes objektif pilihan ganda dengan 4 (empat) alternatif jawaban sebanyak 10 butir soal. Instrumen tes ini dikembangkan sendiri oleh peneliti.

Instrumen tes dalam penelitian ini dibedakan menjadi dua, yaitu: instrumen pre-test dan post-test. Tujuannya untuk mengetahui kemampuan yang telah siswa miliki sebelum dan setelah mendapatkan perlakuan. Soal post-test dibuat sama dengan soal pre-test, tetapi dengan urutan nomor butir soal yang diubah.

Analisis data dilakukan setelah data penelitian terkumpul seluruhnya, baik data yang berasal dari penggunaan media Pembelajaran CLIS maupun Hasil Belajar Siswa, pre-test, maupun post-test. Data-data mentah yang telah terkumpul tersebut kemudian diolah dan dianalisis.Teknik analisis statistik deskriptif dilakukan untuk mendapatkan gambaran penyebaran data penelitian masing-masing variabel sebagaimana adanya, tanpa membuat kesimpulan yang berlaku untuk umum (Sugiyono, 2007:29). Data mentah yang telah dikumpulkan perlu diolah dan diringkas agar dapat dideskripsikan dan mudah dipahami.

Teknik yang digunakan untuk analisis data pada penelitian ini adalah teknik deskriptif analitik dengan penjelasan sebagai berikut:

1. Data kuantitatif yang diperoleh dari hasil tes diolah dengan menggunakan deskripsi persentase. Nilai yang diperoleh siswa dirata-rata untuk menemukan tingkat hasil belajar siswa dalam pembelajaranMatematika

2. Data kualitatif yang diperoleh dari observasi, wawancara dan jurnal diklasifikasikan berdasarkan aspek-aspek yang dijadikan fokus analisis. Data kuantitatif dan kualitatif ini kemudian dikaitkan sebagai dasar untuk mendeskripsikan penggunaan modelpembelajaran CLIS, yang ditandai dengan meningkatnya hasil belajar siswa dalam pembelajaran Matematika secara klasikal.

Penelitian ini dilandasi prinsip kolaboratif dan kooperatif, sehingga penyiapan partisipaan dipandang perlu dilakukan pada kegiatan awal. Melakukan diskusi dengan teman sejawat guru Matematika tentang desain atau strategi pembelajaran pada materi Bangun Ruang yang diikuti dengaan penyusunan rencana kegiatan.

Agar penelitian ini berjalan dengan baik sesuai dengan yang diharapkan maka peneliti bersama teman sejawat dan partisipan melakukan pelatihan dan simulasi pembelajaran dengan menggunakan model pembelajaran CLIS, sehingga pada pelaksanaan pembelajaran dan penelitian tidak ada kesalahpahaman dan perbedaan persepsi yang berkenaan dengan prosedur, proses pembelajaran yang sedang dilakukan penelitian. 
Penelitian ini berlangsung pada bulan Julii sampai dengan bulan September tahun 2017.adapun jadwal penelitian dapat dilihat pada Tabel 1 1erikut.

Tabel 1. Jadwal Peneltian

\begin{tabular}{|c|c|c|c|c|c|c|c|c|c|c|c|c|c|c|c|}
\hline \multirow{2}{*}{ No. } & \multirow{2}{*}{ Uraian Kegiatan } & \multicolumn{5}{|c|}{ Juli } & \multicolumn{4}{|c|}{ Agustus } & \multicolumn{5}{|c|}{ September } \\
\hline & & I & II & III & IV & $\mathbf{V}$ & I & II & III & IV & I & II & III & IV & $\mathbf{V}$ \\
\hline 1. & Persiapan & $\mathrm{V}$ & & & & & & & & & & & & & \\
\hline 2. & $\begin{array}{l}\text { Penyusunan proposal dan } \\
\text { seminar }\end{array}$ & & $\mathrm{V}$ & $\mathrm{V}$ & & & & & & & & & & & \\
\hline 3. & Pelaksanaan Siklus I & & & & & V & & & & & & & & & \\
\hline 4. & Pengumpulan data & & & & & & $\mathrm{V}$ & & & & & & & & \\
\hline 5. & $\begin{array}{l}\text { Analisa dan pengolahan } \\
\text { data }\end{array}$ & & & & & & & $\mathrm{V}$ & & & & & & & \\
\hline 6. & Penelitian Siklus II & & & & & & & & $\mathrm{V}$ & & & & & & \\
\hline 7. & $\begin{array}{l}\text { Analisa dan pengolahan } \\
\text { data }\end{array}$ & & & & & & & & & V & $\mathrm{V}$ & & & & \\
\hline 8. & $\begin{array}{l}\text { Penulisan laporan } \\
\text { penelitian }\end{array}$ & & & & & & & & & & & V & & & \\
\hline 9. & Seminar penelitian & & & & & & & & & & & & $\mathrm{V}$ & & \\
\hline 10. & Revisi & & & & & & & & & & & & & $\mathrm{V}$ & $\mathrm{V}$ \\
\hline
\end{tabular}

\section{Hasil dan Pembahasan}

Paparan Hasil Observasi Pra-siklus

Data hasil pretes kelompok siswa sebelum mendapat perlakuan model pembelajaran CLIS dianalisis dengan untuk mengetahui tingkat pengetahuan dan pemahaman tentang materi belajar yang berhubungan dengan bangun ruang

Tabel 2.Hasil Belajar Siswa Pra Siklus

\begin{tabular}{lll}
\hline No. & Materi Ajar & Rata-rata Nilai \\
\hline 1 & Bangn Ruang & 68,425 \\
Rata-rata nilai & & 68,425 \\
\hline
\end{tabular}

Berdasarkan isi Tabel 2 terlihat bahwa nilai pretes kelompok siswa sebelum mendapat perlakuan pembelajaran dengan model pembelajaran pembelajaran CLIS adalah 68,425.

Paparan Hasil Tindakan Siklus 1

1. Perencanaan Tindakan Siklus 1

Perencanaan di mulai dengan membentuk kelompok diskusi. Siswa yang berjumlah 20 siswa dibagi menjadi 4 (emat) kelompok sehingga masing-masing kelompok berjumlah 5 siswa. Materi pelajaran yang diajarkan pada siklus I ini adalah pokok bahasan Bangun Ruang Proses pembelajaran ini menggunakan model CLIS yang diterapkan oleh guru secara langsung dalam pembelajaran di kelas.

Kegiatan yang dilakukan oleh peneliti pada tahap perencanaan adalah:

a) Peneliti melakukan analisis kurikulum untuk menentukan standar kompetensi dan kompetensi dasar yang disampaikan kepada siswa dengan menggunakan pembelajaran dengan modelpembelajaran berbasid CLIS membuat RPP siklus I dengan model pembelajaran CLIS

b) Membuat lembar observasi siklus I untuk melihat bagaimana kondisi belajar mengajar dikelas ketika latihan dan kerja kelompok dilaksanakan.

c) Membuat Lembar Kerja Siswa siklus I

d) Membentuk kelompok (terdiri dari 5 siswa) yang bersifat heterogen baik dari segi kemampuan akademis, jenis pembelajaran dengan berbased CLIS pada siklus I

e) Menyusun alat evaluasi pembelajaran berdasarkan perkembangan pada siklus II serta menyiapkan instrumen pendukung pembelajaran lainnya. 
2. Pelaksanaan Tindakan Siklus 1

Pelaksanaan kegiatan belajar mengajar pembelajaran dengan model CLIS untuk siklus I dengan jumlah siswa 20 siswa. Dalam hal ini Peneliti bertindak sebagai guru. Pengamatan (observasi) dilaksanakan bersamaan dengan pelaksanaan pembelajaran. Pelaksanaan tindakan siklus I dapat diuraikan sebagai berikut:

a. Guru mengawali pembelajaran dengan mengucapkan salam dan menanyakan jumlah siswa yang hadir.

b. Guru melaksanakan apersepsi.

c. Guru membagi siswa dalam kelompok diskusi, kemudian memberi tugas yang berkaitan dengan penggunaan modelpembelajaran CLIS

d. Guru memberi tugas kepada siswa untuk mempresentasikan di depan kelas hal-hal yang berkaitan Bangun Ruang penggunaan model pembelajaran CLIS, waktu untuk presentasi adalah 3 menit untuk masing-masing kelompok.

e. Guru menindaklanjuti pembelajaran itu dengan menerangkan materi pelajaran tentang hal-hal yang berkaitan dengan Bangun Ruangmenggunakan model pembelajaran berbased CLIS waktu yang digunakan selama 10 menit.

f. Guru bersama-sama siswa mendemonstrasikan penerapan model pembelajaran CLIS materi Bangun Ruang selama 10 menit.

g. Guru bersama-sama siswa melukukan kegiatan diskusi materi bangun ruang

h. Guru memberikan tugas secara individu selama 15 menit

i. Guru menutup pelajaran dengan mengucapkan salam.

Dalam siklus pertama ini, berdasarkan catatan peneliti, siswa masih kurang dapat bekerja sama, kerja kelompok masih kurang dapat berjalan sebagaimana yang diharapkan, presentasi belum banyak mendapat perhatian/tanggapan dari pendengar (siswa dari kelompok lain).

3. Hasil Tindakan Siklus 1

Selama pembelajaran berlangsung dilakukan observasi untuk mengetahui pengaruh kegiatan pembelajaran dalam meningkatkan hasil belajar bangun ruangsiswa dalam proses pembelajaran materi Bangun Ruang. Pada pembelajaran ini siswa yang masuk sebanyak 20 siswa.

Guru mengamati, ternyata pada setiap kelompok masih didapati siswa yang kurang memperhatikan pelajaran yang berkaitan dengan Bangun Ruangdan masih berbicara dengan teman didekatnya tentang hal-hal yang tidak berkaitan dengan materi pembelajaran. Melalui serangkaian pertanyaan yang disampaikan kepada siswa, sebagian diantaranya belum memahami dan bahkan tidak tau apa yang di diskusikan dalam kelompoknya.

Adapun hasil belajar siswa setelah kegiatan yang diberikan dalam Siklus I, dapat dilihat di pada Tabel 3 berikut:

Tabel 3. Hasil Belajar Siswa dalam Siklus 1

\begin{tabular}{llll}
\hline NO & NAMA SISWA & NILAI & PREDIKAT \\
\hline 1 & Ahmad Rayhan P & 80 & Tuntas \\
2 & Aira Putri Nuraini & 70 & Tuntas \\
3 & Ardinia Meisya N & 70 & Tuntas \\
4 & Arga Dwi Dwi Okta S & 80 & Tunas \\
5 & Athya Hyuga S & 60 & Belum Tuntas \\
6 & Avika Laila & 60 & Belum Tuntas \\
7 & Diyah Wulan & 70 & Tuntas \\
8 & Efan Aditya & 80 & Tuntas \\
9 & Evan Ekta Ardinata & 50 & BelumTuntas \\
10 & Friska Adelia & 60 & Belum tuntas \\
11 & Keyza Shabila L & 70 & Tuntas \\
12 & Lailani Aqilah Z & 70 & Tuntas \\
13 & Nazifa Hidayani & 90 & Tuntas \\
14 & Retno Ayu R & 60 & Belum Tuntas \\
15 & Reza Suryo O & 75 & Tuntas \\
16 & Septa Azril Saputra & 70 & Tuntas \\
17 & Susilo Dwi Arta & 60 & Belum tuntas \\
\hline
\end{tabular}




\begin{tabular}{llll}
\hline NO & NAMA SISWA & NILAI & PREDIKAT \\
\hline 18 & Vika Marsha A & 80 & Tuntas \\
19 & Muh Pratama P & 60 & Belum tuntas \\
20 & Naura Azzahra R & 90 & Tuntas \\
& Jumlah & & \\
& Rata-rata & & \\
\hline
\end{tabular}

Dari tabel di atas dapat diketahui bahwa dengan menerapkan pembelajaran pendekatan pembelajaran CLIS tampak bahwa nilai rata-rata siswa adalah 70,28 dengan nilai terendah 60 dan nilai tertinggi 90. Nilai ketuntasan belajar adalah 7,0 jumlah siswa yang mendapat nilai $\geq 7,0$ sebanyak 15 siswa, yang berarti $75 \%$ dari sejumlah 20 siswa memiliki nilai di atas taraf penguasaan konsep yang diberikan, lebih kecil dari persentase ketuntasan yang dikehendaki yaitu sebesar $95 \%$. Hal ini disebabkan karena siswa masih baru dan asing terhadap metode baru yang diterapkan dalam proses belajar mengajar. Sehingga dapat dikatakan siswa belum banyak memahami tentang konsep pokok bahasan yang dibahas.

4. Refleksi Tindakan Siklus 1

Dalam pelaksanaan kegiatan belajar mengajar pada siklus I yang masih terdapat kekurangan-kekurangan, Maka perlu adanya revisi untuk dilakukan pada siklus II antara lain :

a. Guru dalam memotifasi siswa hendaknya dapat membuat siswa lebih termotivasi selama proses belajar mengajar berlangsung.

b. Guru harus lebih dekat dengan siswa sehingga tidak ada perasaan takut dalam diri siswa, sehingga siswa lebih berkosentrasi dalam pembelajaran.

c. Guru harus lebih bersabar dalam membimbing siswa berdiskusi untuk menemukan hal-hal baru yang berkaitan dengan materi pembelajaran.

d. Guru secara intensif memberikan pengertian kepada siswa kondisi dalam berkelompok, kerjasama kelompok, dan keikutsertaan siswa dalam kelompok.

e. Guru mengubah jumlah siswa (dari 5 siswa menjadi 4 siswa) dalam satu kelompok.

f. Guru membantu kelompok yang belum memahami langkah-langkah model pembelajaranpembelajaran CLIS

g. Guru memberikan dorongan dan motivasi kepada siswa untuk lebih aktif mencari sumber belajar, diharapkan agar siswa memperoleh hasil yang diharapkan.

Paparan Hasil Tindakan Siklus II

1. Perencanaan Tindakan Siklus II

Perencanaan di mulai dengan membentuk kelompok diskusi. Siswa yang berjumlah 20 siswa dibagi menjadi 5 kelompok sehingga masing-masing kelompok berjumlah 4 siswa. Materi pelajaran yang diajarkan pada siklus II ini tetap pada pokok bahasan Bangun ruang Proses pembelajaran pokok bahasan ini menggunakan model pembelajaran CLIS yang diterapkan oleh guru secara langsung dalam pembelajaran di kelas.

Kegiatan yang dilakukan oleh peneliti spada tahap perencanaan pada siklus II adalah:

a. Peneliti melakukan analisis kurikulum untuk menentukan Standar Kompetensi dan Kompetensi Dasar yang disampaikan kepada siswa dengan menggunakan model pembelajaran CLIS. Membuat RPP dengan model pembelajaran pendekatan pembelajaran pembelajaran CLIS siklus II

c. Membuat lembar observasi siklus II untuk melihat bagaimana kondisi belajar mengajar di kelas ketika latihan dan kerja kelompok dilaksanakan.

d. Membuat Lembar Kerja Siswa siklus II

e. Membentuk kelompok (terdiri dari 4 siswa) yang bersifat heterogen baik dari segi kemampuan akademis, model pembelajaran CLIS pada siklus II

f. Menyusun alat evaluasi pembelajaran berdasarkan perkembangan pada siklus II serta menyiapkan instrumen pendukung pembelajaran lainnya

2. Pelaksanaan TindakanSiklus II

Pelaksanaan kegiatan belajar mengajar dengan model pembelajaran pembelajaran CLIS untuk siklus II dilaksanakan di kelas I A SDN Candiwatu Pacet dengan jumlah siswa 20 anak dengan materi bangun ruang. Dalam hal ini Peneliti bertindak sebagai guru. Pengamatan (observasi) dilaksanakan bersamaan dengan pelaksanaan pembelajaran. Pelaksanaan tindakan disesuaikan dengan RPP (Rencana Pelaksanaan Pembelajaran) dan lembar kerja yang telah dibuat dan mengacu pada revisi siklus I, sehingga kekurangan-kekurangan pada siklus I tidak terulang pada siklus II. 
Adapun proses belajar mengajar mengacu pada rencana pembelajaran yang telah dipersiapkan dengan menggunakan metode pembelajaran CLIS, dengan tahapan, presentasi kelas, kerja kelompok, tes individu,dan penghargaan kelompok.

Pelaksanaan tindakan siklus II dapat diuraikan sebagai berikut:

a.Guru mengawali pembelajaran dengan mengucapkan salam dan menanyakan jumlah siswa yang hadir.

b.Guru melaksanakan apersepsi.

c.Guru membagi siswa dalam kelompok diskusi, kemudian memberi tugas yang berkaitan dengan penggunaan model pembelajaran CLIS. Guru memberi tugas kepada siswa untuk mempresentasikan di depan kelas hal-hal yang berkaitan bangun ruang menggunakan model pembelajaran CLIS, waktu untuk presentasi adalah 3 menit untuk masing-masing kelompok.

d.Guru menindaklanjuti pembelajaran itu dengan menerangkan materi pelajaran tentang hal-hal yang berkaitan dengan bangun ruang menggunakan model pembelajaran CLIS, waktu yang digunakan selama 10 menit.

e.Guru bersama-sama siswa mendemonstrasikan penggunaan model pembelajaran CLIS materi bangun ruangselama 10 menit.

f. Guru bersama-sama siswa melukukan kegiatan kewirausahaan materi bangun ruang

g.Guru memberikan tugas secara individu selama 15 menit

h.Guru menutup pelajaran dengan mengucapkan salam.

3. Hasil Tindakan Siklus II

Selama pembelajaran berlangsung dilakukan observasi untuk mengetahui penerapan model pembelajaran CLIS dalam meningkatkan hasil belajar siswa dalam proses pembelajaran materi Bangun ruang. Pada pembelajaran ini siswa yang masuk sebanyak 20 siswa.

Bila dilihat dari angka aktivitas guru dan siswa selama kegiatan belajar mengajar, maka secara keseluruhan aktivitas guru dan siswa menunjukkan pembelajaran yang berorientasi pendekatan keterampilan proses dalam setting pembelajaran CLIS berpusat pada siswa, dimana siswa terlibat aktif dalam pembelajaran.

Pada akhir proses belajar mengajar siklus II siswa diberi tes dengan tujuan untuk mengetahui tingkat keberhasilan siswa dalam proses belajar mengajar yang sudah dilakukan di siklus I, kemudian dikomparasikan dengan hasil pada siklus II.

Dalam pembelajaran siklus II, konsep-konsep yang teridentifikasi dikembangkan lebih lanjut. Dalam Siklus II ini, berdasarkan catatan peneliti, kerjasama siswa sudah berjalan dengan baik, sehingga masing-masing siswa dapat memecahkan masalah secara individual. Adapun data hasil tes pada siklus II adalah sebagai berikut:

Tabel 4. Nilai Tes Formatif Siswa dalam Siklus 2

\begin{tabular}{llll}
\hline NO & NAMA SISWA & NILAI & PREDIKAT \\
\hline 1 & Ahmad Rayhan P & 80 & Tuntas \\
2 & Aira Putri Nuraini & 90 & Tuntas \\
3 & Ardinia Meisya N & 76 & Tuntas \\
4 & Arga Dwi Dwi Okta S & 80 & Tunas \\
5 & Athya Hyuga S & 80 & Tuntas \\
6 & Avika Laila & 80 & Tuntas \\
7 & Diyah Wulan & 77 & Tuntas \\
8 & Efan Aditya & 80 & Tuntas \\
9 & Evan Ekta Ardinata & 75 & Tuntas \\
10 & Friska Adelia & 84 & Ttuntas \\
11 & Keyza Shabila L & 80 & Tuntas \\
12 & Lailani Aqilah Z & 80 & Tuntas \\
13 & Nazifa Hidayani & 90 & Tuntas \\
14 & Retno Ayu R & 76 & Tuntas \\
15 & Reza Suryo O & 75 & Tuntas \\
16 & Septa Azril Saputra & 80 & Tuntas \\
17 & Susilo Dwi Arta & 60 & Belum Tuntas \\
18 & Vika Marsha A & 80 & Tuntas \\
19 & Muh Pratama P & 75 & Tuntas \\
20 & Naura Azzahra R & 90 & Tuntas \\
\hline
\end{tabular}


Dari tabel di atas tampak bahwa hasil nilai evaluasi rata-rata siswa secara individual adalah 80,4 dengan nilai terendah 60 dan nilai tertinggi 90. Data diatas menunjukkan bahwa pada siklus II ini, nilai siswa secara individual mengalami peningkatan, yaitu siswa yang tuntas sebanyak 19 siswa dan yang belum tuntas sebanyak 1 siswa, yang berarti 95\% dari sejumlah 20 siswa memiliki nilai di atas taraf penguasaan konsep yang diberikan. Dari siklus 2 ini dapat dikatakan bahwa proses pembelajaran dengan model pembelajaran pendekatan pembelajaran CLIS dapat meningkatkan hasil belajar siswa.

4. RefleksiTindakan Siklus II

Dalam pelaksanaan kegiatan belajar mengajar pada siklus II ini masih terdapat kekurangankekurangan. Pada tahap ini akan merefleksikan kembali apa yang telah dilaksanakan selama penelitian tindakan kelas dilakukan. Dari data yang diperoleh dapat diuraikan sebagai berikut:

a.Selama proses belajar mengajar guru telah melaksanakan pembelajaran dengan cukup baik dengan model pembelajaranpembelajaran CLIS, meskipun ada beberapa bagian yang masih belum sempurna, tetapi presentasi pelaksanaan untuk masing-masing kegiatan sudah cukup baik.

b.Berdasarkan data hasil lembar observasi kegiatan kelompok siswa, diadakan perubahan jumlah kelompok pada siklus I sebanyak 5 siswa, dan pada siklus II sebanyak 4 siswa.

c.Kekurangan pada siklus I diperbaiki, sehingga pembelajaran menjadi lebih baik pada siklus II.

d.Hasil evaluasi siswa mengalami peningkatan dari siklus I ke siklus II, dan telah mencapai ketuntasan belajar pada siklus II ini sesuai yang diharapkan yakni peningkatan hasil belajar siswa.

Pembahasan Antar siklus

Sebelum perlakuan diberikan pada masing-masing kelompok, nilai rerata pretes siswa sebelum diberi perlakuan pembelajaran dengan model pembelajaran CLIS adalah 69,425. Setelah siswa diberi perlakuan pembelajaran dengan model pembelajaran CLIS pada siklus I mengalami peningkatan menjadi 70.28, namun hasil ini belum memenuhi target hasil belajar siswa mata pelajaran Matematikadan kewirausahaan yaitu $95 \%$.

Bila dihitung berdasarkan nilai rerata pretes, kelompok siswa yang diberi perlakuan pembelajaran dengan model pembelajaran pembelajaran CLIS.Setelah dilaksanaknnya siklus ke II mengalami peningkatan rerata hasil belajar sebesar 80,400-69,425 $=10,975$.

Berdasarkan hasil pada sisklus penelitian tersebut di atas, dapat ditunjukkan bahwa ada perbedaan hasil belajar bangun ruangantara siswa yang diajar menggunakan metode pembelajaran dengan dibantu model pembelajaranpembelajaran CLIS. Hasil penelitian ini juga didukung oleh hasil penelitian Alma (2012) yang menyatakan bahwa ada perbedaan hasil belajar siswa yang yang mendapat perlakuan pembelajaran dengan model pembelajaran CLIS memperoleh rata-rata nilai sebesar 80,400, lebih tinggi daripada sebelum siswa diajar dengan model pembelajaran lainnya, yaitu 69,425.Penerapan pembelajaran dengan model pembelajaran pembelajaran CLISmemberikan peningkatatan yang lebih baik pada perolehan hasil belajar bangun ruangdaripada penerapan pembelajaran dengan metode lainya. Dengan kata lain dapat diinterpretasikan bahwa penerapan pembelajaran dengan model pembelajaran CLISdapat meningkatkan perolehan hasil belajar siswa pada materi bangun ruangdaripada dengan model pembelajaran lain. Selain itu penelitian oleh Widyarti (2012) menyatakan bahwa dalam tahapan CLIS, kreativitas juga mengalami perkembangan artinya dalam proses pembelajaran siswa tidak hanya sekedar mendengar, mencatat, kemudian menghapal materi saja, akan tetapi dapat memberikan pengalaman langsung kepada siswa dengan cara mengamati dan melakukan penelitian.

\section{Simpulan dan Saran}

Penerapan pem $\neg$ belajaran dengan model pembelajaran CLIS memberikan peningkatatan yang lebih baik pada perolehan hasil belajar bangun ruangdari $\neg$ pada penerapan pem $\neg$ belajaran dengan metode lainya. Dengan kata lain dapat diinter-pretasikan bahwa penerapan pem $\neg$ belajaran dengan model pembelajaran CLISdapat meningkatkan perolehan hasil belajar siswa pada materiBangun ruangdaripada dengan model pem belajaran lainnya. Hal ini berdasarkan nilai rerata pretes dimana rata-rata hasil belajar siswa sebesar 68,425 , sedangkan setelah siswa diberi perlakuan pem $\neg$ belajaran dengan metode role playing setelah dilaksanaknnya siklus ke II mengalami peningkatan rerata hasil belajar sebesar 80,400 artinya terjadi peningkatan rerata hasil belajar siswa sebesar 10,975.

Adpun saran yang dapat peneliti sampaikan antara lain: 1) Hendaknya guru mampu menciptakan suasana kelas yang kondusif sehingga siswa tidak merasa takut, 2) Sebelum melaksanakan pembelajaran hendaknya guru mempersiapkan terlebih dahulu bahan dan alat pembelajaran demi kelancaran kegiatan, 3) Sebelum melakukan pembelajaran di kelas, Guru mampu melakukan setting kelas sesuai rencana, 4) Hendaknya guru melaksanakan model pembelajaran berbasis model pembelajaran pembelajaran CLIS 
secara konsisten. Dengan demikian diharapkan hasil belajar siswa akan lebih meningkat, 5) Hendaknya guru mengadakan kegiatan refleksi dengan guru lain dalam wadah KKG tentang berbagai masalah pembelajaran dengan penggunaan strategi pembelajaran CLIS yang dilakukan sehari-hari, dan 6) Hendaknya kepala sekolah mendukung penuh dan memberikan motivasi kepada para guru untuk selalu menggunakan model pembelajaran CLIS guna meningkatkan hasil belajar siswa.

\section{Daftar Rujukan}

Asep Jihad (2008:152-153) karakteristik yangmembedakan matematika dengan pelajaran yang lain

Budiarti, Luh Putu Yudha, Gede Raga, I Wayan Romi Sudhita. 2014. Pengaruh Model Pembelajaran Clis Terhadap Hasil Belajar Ipa Siswa Kelas Iv Sd Di Gugus Iii Kecamatan Busungbiu. Jurnal Mimbar PGSD Universitas Pendidikan Ganesha Jurusan PGSD Vol: 2 No: 1

Dewi, P. Nym. T. T, Suadnyana, I Ngh \&Negera, I Gst. A. O. (2014 Pengaruh Model Children's Learning In Science Berbantuan Media Powerpoint Terhadap Hasil Belajar IPA Siswa Kelas V SD. Jurnal Mimbar PGSD UniversitasJurnal Mimbar PGSD Universitas Pendidikan Ganesha Jurusan PGSD, (2)

Irawati, Abdul Samad, Nurlina. 2014. Penerapan Model Pembeajaran CLIS Terhadap Hasil Belajar Peserta Didik Kelas VIII7 SMP Negeri 1 Pallangga Kabupaten Gowa. JPF | Volume 2 | Nomor 3 |Hal. 183-191. Tersedia Pada: https://journal.unismuh.ac.id/index.php/jpf/article/view/234.

Ismail, A. (2015). Penerapan Model Tingkat Satuan Pendidikan (KTSP). Pembelajaran Children Learning In Jakarta: Bumi Aksara. Science (CLIS) Berbantuan Multimedia Untuk Meningkatkan Penguasaan Konsep Fisika Siswa SMA. Petik.

Joko, T., Ahdinirwanto, R. W. \& Maftukhin, A. (2013). Peningkatan Kemampuan Berfikir Kritis Melalui Model Pembelajaran Children Learning In Science (CLIS) pada Siswa Kelas VIII SMP Negeri 1 Mirit Tahun Pelajaran 2012/2013.

Marlina, D. (2016). Pengaruh Konsep Diri dan Kedisiplinan Belajar Terhadap Penguasaan Konsep IPA. Premiere Educandum,

Noprianti, I. D. \& Syarifuddin, A. (2015). Pengaruh Penerapan Media Slide Power Point Terhadap Hasil Belajar Siswa Kelas III Pada Mata Pelajaran IPA di Madrasah Ibtidaiyah Ahliyah 2 Palembang. Volume 1

Nurani, Lilis Endah. 2017. Pengaruh Model Pembelajaran Children Learning In Science (CLIS) Dengan Pemanfaatan Lingkungan Sebagai Sumber Belajar terhadap Kemampuan Mendeskripsikan Bagian Bunga dan Fungsinya pada Siswa Kelas IV SDN Gayam Kecamatan Mojoroto Kota Kediri Tahun Ajaran 2016/2017. Simki-Pedagogia Vol. 01 No. 02 Hal. 1-12. Tersedia Pada: http://simki.unpkediri.ac.id/mahasiswa/file_artikel/2017/27fd3066a855681d9a7bd4ebcf59a97d. pdf.

Rusman.2012.Model-Model Pembelajaran. Bandung: Raja Grafindo Persada.

Samatowa, Usman. 2010. Pembelajaran IPA di Sekolah Dasar. Cetakan Ke-1. Jakarta: Indeks.

Sri Subarina (2006: 36) Mengayakan bahwa bangun ruang merupakan bangun geometri dimensi 3 dengan batas-batas berbentuk bidang datar dana atau bidang lengkung

Sugiyono. (2015). Metode Penelitian Kuantitatif Kualitatif dan R\&D. Bandung: Alfabeta.

Susanto, A. (2013). Teori Belajar \& Pembelajaran di Sekolah Dasar. Jakarta: Kencana Prenada Media Group.

Sutarno, N. (2009). Materi dan Pembelajaran IPA SD. Jakarta: Universitas Terbuka. 
Sumanto dkk. (2008: 149) mengemukakan bahwa bangun ruang memiliki sifat-sifat terntentu ,yaitu memiliki sisi,rusuk, dan titik sudut.

Suryani, Novi Ade, Indra Sakti, Andik Purwanto. 2018. Perbedaan Hasil Belajar Antara Model Pembelajaran CLIS (Children's Learning In Science) dengan Menggunakan Media KIT IPA di SMP Negeri 21 Kota Bengkulu. Pendipa Journal of Science Education, 2018: 2 (1) Hal. 113-116. Tersedia Pada: https://ejournal.unib.ac.id/index.php/pendipa/article/view/4793.

Trianto. (2014). Model Pembelajaran Terpadu Konsep, Strategi, dan Implementasinya dalam Kurikulum Tingkat Satuan Pendidikan (KTSP). Jakarta: Bumi Aksara.

Widyarti, Aktris, dkk. 2012. "Pengaruh Model Pembelajaran CLIS (Children Learning In Science) dalam Meningkatkan Kreativitas dan Prestasi Siswa Pada Mata Pelajaran IPA". Prosiding Seminar Nasional, Pendidikan dan Penerapan MIPA. Fakultas MIPA. Universitas Negeri Yogyakarta, 2 Juni 2012 